\title{
Arbuscular mycorrhizae inoculation of einkorn wheat affects fatty acid, nutrient and mineral concentrations
}

\author{
T. Ayaşan ${ }^{1 \#}$, S. Esen ${ }^{2}$, V. Kader Esen ${ }^{3}$, H. Eseceli ${ }^{4}$ \& E. Cabi ${ }^{2}$ \\ ${ }^{1}$ Osmaniye Korkut Ata University, Kadirli Academy of Applied Sciences, Osmaniye, Turkey \\ ${ }^{2}$ Tekirdağ Namık Kemal University, Department of Biology, Tekirdağ, Turkey \\ ${ }^{3}$ Bursa Uludağ University, Faculty of Agriculture, Department of Animal Science, Bursa, Turkey \\ ${ }^{4}$ Kastamonu University, Faculty of Veterinary, Department of Animal Nutrition and Nutritional Diseases, Kastamonu, \\ Turkey
}

(Submitted 5 May 2020; Accepted 25 June 2020; Published 26 September 2020)

Copyright resides with the authors in terms of the Creative Commons Attribution 4.0 South African Licence.
See: http://creativecommons.org/licences/by/4.0/za
Condition of use: The user may copy, distribute, transmit and adapt work, but must recognise the authors and the South African Journal
of Animal Science.

\begin{abstract}
The purpose of this study was to determine the effect of arbuscular mycorrhizae (AM) inoculation, which was administered to increase the quality of einkorn wheat in its fatty acid composition, quality and mineral concentration. Wheat grown from $A M$ inoculated seed $(A M+)$ had increased the dry matter (DM), iron (Fe), monounsaturated fatty acids (MUFA), especially oleic acid, and alpha-linolenic acid, and cis-5,-8,-11,14 , and cis-17 eicosapentaenoic acid from polyunsaturated fatty acids (PUFA) $(P<0.05)$, but decreased crude ash (CA), potassium (K), and total saturated fatty acids (UFA), especially myristic acid, palmitic acid, stearic acid and monounsaturated fatty acids, especially cis-palmitoleic acid, cis-10-heptadecenoic acid, cis11 eicosenoic acid, erucic acid, and linoleic acid $(P<0.05)$ compared with einkorn wheat grown from noninoculated seed (AM-). Crude protein (CP) content ranged from $10.56 \%$ to $10.68 \%$, and ether extract (EE) content varied between $2.03 \%$ and $2.41 \%$, neither of which was significantly different between treatments. Significant increases were observed in UFA, and in the ratios of UFA to SFA and PUFA to SFA in AM+ compared with AM-.
\end{abstract}

Keywords: mycorrhizal inoculation, nutrient composition, Triticum monococcum

\#Corresponding author: tayasan@gmail.com

\section{Introduction}

Arbuscular mycorrhizal fungi are naturally ubiquitous and beneficial fungi in agricultural ecosystems. These fungi have symbiotic relationships with many cereal crops (Smith \& Smith, 2011), in which they have an active role in providing mineral nutrients to plants (Somenahallya et al., 2018). Akpınar (2011) reported that the most important benefit of mycorrhiza is the expanded surface area of roots of plants that have coarse and weakly structured root systems, thus increasing the uptake of nutrients from the soil. Thus, mycorrhizal inoculated barley had greater CP content, but less ADF and ADL than a control group that was not inoculated (Sabia et al., 2015).

Einkorn wheat (Triticum monococcum) was one of the first cultivated wheat varieties. Although it originated in Turkey, it is cultivated in the Balkans. Einkorn wheat is important in human health, and human and animal nutrition and is one of the most popular products of the organic market. Einkorn wheat bread has not been gene edited and has a low risk of inducing allergic reactions. It is rich in vitamins, minerals, and antioxidants and has some positive effects on human health (Hidalgo \& Brandolini, 2014). It has higher levels of $\mathrm{CP}$, phosphorus $(\mathrm{P})$, and $\mathrm{K}$ compared with other varieties of wheat. It is also used as an animal feed and as the main ingredient in cakes and breads (Nakov et al., 2016). Unlike modern cultivars, einkorn wheat has a pair of each of 14-chromosomes. It can be consumed as bulgur by humans and its grain and straw can be fed to animals. With its tight husk structure, einkorn wheat is resistant to diseases and pests and is highly competitive in dry conditions and in infertile soils (Kastamonu Chamber of Commerce, 2019). These attributes make it a putative source of new and useful genes, and a crop that has good agri-biological properties (Nakov et al., 2016). 
Recent concerns have led to increased demand for healthy foods and products, which has increased the requirement for bulgur made from einkorn wheat (Erba et al., 2011; Karabak et al., 2019). Ertop (2019) reported that einkorn wheat contained $12.74 \% \mathrm{CP}, 89.91 \% \mathrm{DM}, 2.48 \%$ ash, $2.51 \%$ fat, and $10.76 \%$ total cellulose. An analysis of the fatty acid composition of einkorn wheat distinguished at least 14 compounds (Hidalgo \& Brandolini, 2014; Nakov et al., 2016). Gabrovská et al. (2002) found the fatty acid contents in einkorn wheat $(\mathrm{g} / 100 \mathrm{~g})$ included myristic acid, 0.18; myristoleic acid, 0.08; palmitic acid, 13.9; palmitoleic acid, 0.21; stearic acid, 0.87; oleic acid, 25.3; linoleic acid, 54; linolenic acid, 3.60; arachidic acid, 0.15; cis-11-eicosenoic acid, 1.36; behenic acid, 0.14; and erucic acid, 0.23. Hidalgo and Brandolini (2014) asserted that linoleic acid (C18:2n6), oleic acid (C18: $1 \mathrm{n} 9+\mathrm{C} 18: 1 \mathrm{n} 7)$, and palmitic acid (C16:0) acid were the most prevalent fatty acids in einkorn wheat, comprising $50.9-54 \%, 24.8-26.4 \%$, and $13.9-16.7 \%$, respectively, of total fatty acids.

In Turkey, einkorn wheat is grown mostly in Kastamonu (Emeksizoğlu, 2016). In 2016, einkorn wheat was sown on 783.5 ha in the region and produced 1959 tons (Kastamonu Chamber of Commerce, 2019). In this study, the effect of AM inoculation on the fatty acid, nutrient, and mineral contents of einkorn wheat was examined.

\section{Materials and methods}

The field experiment was conducted at a commercial farm in Pinarbasi, Kastamonu (41.55 N, 33.10 E), Turkey. There were two treatments, namely wheat grown from seed with and without AM inoculation ( $\mathrm{AM}+$ and $\mathrm{AM}-$, respectively). The einkorn wheat was planted in mid-November 2018 and the grain was harvested in late July 2019. A total of 5 ha was cultivated with einkorn wheat. The seed used on 4.5 ha was AM-, but the seed used on the remaining 0.5 ha was $A M+$. Three random samples were collected from each treatment while harvesting.

The einkorn wheat seed was inoculated with AM fungi before sowing. The AM spores were collected from the rhizosphere soil of maize plants (Gerdemann \& Nicolson, 1963) and were identified as a mixture of Glomus spp. according to their morphological characteristics (Schenck \& Perez, 1990). The Glomus spp. was mixed with silicon dioxide $(1: 1 \mathrm{w} / \mathrm{w})$, which served as an aid to coating the einkorn wheat seed (Merck, Darmstadt, Germany). Abnormal grains were removed and then the remainder were coated by gradually adding the inoculum-coating mixture, according to the pan-coating method (Scott et al., 1991) and air-dried at $24 \pm 2{ }^{\circ} \mathrm{C}$ for 72 hours. Non-inoculated control seeds were coated only with silicon dioxide.

After harvesting, all samples were milled through a $1-\mathrm{mm}$ sieve, transported to the laboratory, and stored in glass jars for further chemical analyses. All chemical analyses were carried out in triplicate. In the laboratory, the DM, CP, CA, EE, and crude fibre (CF) content of the samples were determined using AOAC methods (AOAC, 1990).

The $\mathrm{Zn}, \mathrm{Cu}, \mathrm{Fe}$, sodium $(\mathrm{Na})$, and $\mathrm{K}$ contents of the milled wheat were measured in this study. Approximately $0.5 \mathrm{~g}$ of sample was weighed into a vessel that was resistant to temperature and pressure, with $8 \mathrm{~mL}$ nitric acid and $2 \mathrm{~mL}$ hydrogen peroxide for microwave digestion. The digested sample was allowed to cool before being transferred quantitatively into clean Falcon tubes, completed to $25 \mathrm{~mL}$ final volume with deionized water, and analysed with a Shimadzu AA-7000 (Shimadzu Corporation, Kyoto, Japan) flame atomic absorption spectrophotometer (Milestone, 2009).

Lipids were extracted from the einkorn wheat with diethyl ether according to AOAC (1990). The diethyl ether extracts were evaporated to dryness and resuspended in $10 \mathrm{~mL}$ hexane and $0.5 \mathrm{~mL} 2 \mathrm{~N} \mathrm{KOH}$ for at least two hours in a dark place. Then, the clear upper phase was passed through the $0.45 \mu \mathrm{m}$ PTFE filter and transferred to the vials (Tanacı, 2015). A GC-2010 Plus gas chromatograph (Shimadzu Corporation, Kyoto, Japan) equipped with flame ionization detector (FID) and a TR-CN100 (Teknokroma, Barcelona, Spain) capillary column $(60 \mathrm{~m} \times 0.25 \mathrm{~mm} \times 0.20 \mu \mathrm{m})$ was used for analyses. Hydrogen was used as the carrier gas and the flow rate was controlled at $40 \mathrm{ml} \mathrm{min}^{-1}$. The injector temperature was kept at $250{ }^{\circ} \mathrm{C}$ and the injection amount of the sample was $1.0 \mu \mathrm{L}$. The column temperature procedure was started at $90^{\circ} \mathrm{C}$ and held for $4 \mathrm{~min}$, then heated up to $240^{\circ} \mathrm{C}$ at $3^{\circ} \mathrm{C}$ per min, and held at $240{ }^{\circ} \mathrm{C}$ for $12 \mathrm{~min}$. The peaks were identified with Supelco 37 component FAME mix according to area normalization.

One-way analysis of variance was performed using SAS (JMP version 13.2, SAS Institute Inc., Cary, North Carolina, USA) to determine the effects of treatment on the nutritive value, concentrations of selected minerals and fatty acids composition. The level of significance between individual means was determined using student's t-test. Differences were considered significant at $P \leq 0.05$.

\section{Results and Discussion}

The effects of $\mathrm{AM}$ inoculation on the nutrient composition and mineral content of einkorn wheat are shown in Table 1. 
Table 1 Comparison between nutrient composition of einkorn wheat grown from seed inoculated with arbuscular mycorrhizae and control

\begin{tabular}{|c|c|c|c|c|}
\hline & Control & Inoculated & SE & $P$-value \\
\hline Dry matter, $\mathrm{g} \mathrm{kg}^{-1}$ & $915.3^{b}$ & $949.0^{a}$ & 2.12 & 0.0004 \\
\hline Crude protein, $\mathrm{g} \mathrm{kg}^{-1}$ & 105.6 & 106.8 & 0.56 & 0.2159 \\
\hline Ether extract, $\mathrm{g} \mathrm{kg}^{-1}$ & 20.3 & 24.1 & 1.67 & 0.2491 \\
\hline Crude fibre, $\mathrm{g} \mathrm{kg}^{-1}$ & 104.3 & 95.5 & 3.05 & 0.1123 \\
\hline Crude ash, $\mathrm{g} \mathrm{kg}^{-1}$ & $62.3^{\mathrm{a}}$ & $58.1^{\mathrm{b}}$ & 0.37 & 0.0013 \\
\hline Zinc, mg $100 \mathrm{~g}^{-1}$ & 3.71 & 3.70 & 0.03 & 0.7284 \\
\hline Copper, mg $100 \mathrm{~g}^{-1}$ & 0.24 & 0.26 & 0.01 & 0.1979 \\
\hline Iron, $\mathrm{mg} 100 \mathrm{~g}^{-1}$ & $4.93^{\mathrm{b}}$ & $7.79^{\mathrm{a}}$ & 0.17 & 0.0003 \\
\hline Sodium, mg $100 \mathrm{~g}^{-1}$ & 3.14 & 2.36 & 0.40 & 0.2348 \\
\hline Potassium, mg $100 \mathrm{~g}^{-1}$ & $600.2^{\mathrm{a}}$ & $558.8^{b}$ & 5.39 & 0.0056 \\
\hline
\end{tabular}

The DM content of $\mathrm{AM}+$ and $\mathrm{AM}$ - differed significantly in this study. However, both were greater than the $89.81 \%, 89.69 \%$, and $88.95 \%$ DM found by Ertop (2019), Ertop and Atasoy (2019), and Vrancheva et al. (2019), respectively.

The treatments in this study did not affect the CP content of the einkorn wheat significantly $(P>0.05)$. Sabia et al. (2015) reported that AM+ barley contained more CP than AM- barley $(9.5 \%$ and $8.1 \%$,). They also found that when berseem clover seed was inoculated with mycorrhizae the crop contained more CP than the crop from non-inoculated seed (12.7\% and 12.2\%). Numerous studies found CP levels in einkorn wheat that were comparable with or higher than those observed in the present study (Sachambula et al., 2015, 15.8\%; Arzani \& Ashraf, 2017, 15.5 - 22.8\%; Patijn et al., 2018, 10.5 - 11.7\%; Costanzo et al., 2019, $12 \%)$.

The treatments did not affect the EE content of the einkorn wheat $(P>0.05)$. Similarly, Sabia et al. (2015) observed that the EE contents of the mycorrhizal inoculated barley and berseem clover were similar to the non-inoculated controls. In a variety of studies (e.g. Şanal, 2018; Costanzo et al., 2019; Abdel-Aal \& Hucl, 2014), the fat content or EE of einkorn wheat was found to vary between $1.8 \%$ and $4.4 \%$. This variation might stem from the differences in analytical methods, places of cultivation, and country, and whether it was the main or the second crop. Brandolini and Hidalgo (2011) reported that the fat content of einkorn wheat was higher than that of other wheat varieties $(4.2 \mathrm{~g} / 100 \mathrm{~g}$ vs. $2.8 \mathrm{~g} / 100 \mathrm{~g})$.

The AM+ did not affect the CF content of the resulting plants $(P>0.05)$. Sabia et al. (2015) found similar values $(P>0.05)$ for the CF content of mycorrhizal inoculated barley $(25.7 \%)$ and the non-inoculated one (25.7\% and $26.0 \%)$. However, Sabia et al. (2015) observed an increase in the CF content of berseem clover (17.6\%) grown from inoculated seed compared with clover grown from seed that was not inoculated (16.5\%). Luje et al. (2013), Abdel-Aal and Hucl (2014) and Ertop (2019) reported the cellulose levels in einkorn wheat were $7.6-9.9 \%, 8.7 \%, 10.76 \%$, respectively.

The AM+ treatment decreased the CA content in the grain that was produced $(P<0.05)$. The levels of $C A$ observed in the present study were greater than those observed in previous studies of einkorn wheat (e.g. Abdel-Aal \& Hucl, 2014; Şanal, 2018; Ertop, 2019; Vrancheva et al., 2019), in which the average CA content was $2.2 \%$. Luje et al. (2013) found the CA content of einkorn wheat was only slightly higher than was observed in the previously mentioned studies at $2.3-2.8 \%$. In contrast with the present results, Sabia et al. (2015) did not detect significant differences in the CA content of barley owing to the mycorrhizal inoculation of the seed.

Adıgüzel (2019), stated that the mineral content of einkorn wheat grain varied, depending on the climate, soil, and genotype. In examining the treatment effects on the content of $\mathrm{Zn}, \mathrm{Cu}, \mathrm{Fe}, \mathrm{Na}$, and $\mathrm{K}$, only $\mathrm{Fe}$ and $\mathrm{K}$ differed as a result of seed inoculation $(P<0.05)$, with the $\mathrm{Fe}$ content being increased whereas the $\mathrm{K}$ content was decreased. Ozkan et al. (2007) stated that the Fe content in einkorn wheat varied depending on the genotype and averaged $4.70 \mathrm{mg} 100 \mathrm{~g}^{-1}$, which is a lower level than was observed in the present

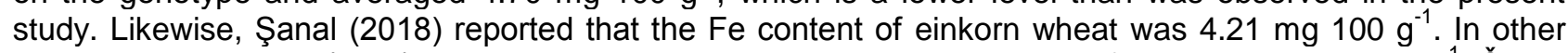

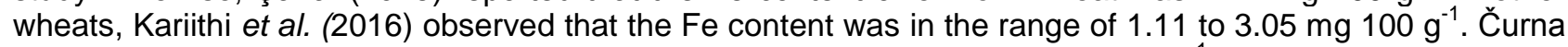
and Lacko-Bartošová (2017) reported it was between 3.82 and $5.55 \mathrm{mg} 100 \mathrm{~g}^{-1}$ (4.59 on average), and 


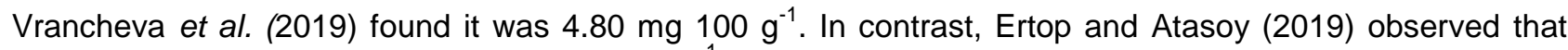

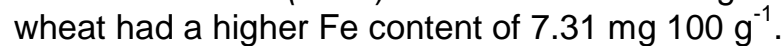

Abdel-Aal et al. (1995), Gabrovská et al. (2002), Grain Nutrition Comparison (2009), and Şanal (2018) observed that the $\mathrm{K}$ content of einkorn wheat was approximately $390-400 \mathrm{mg} 100 \mathrm{~g}^{-1}$. Hidalgo and

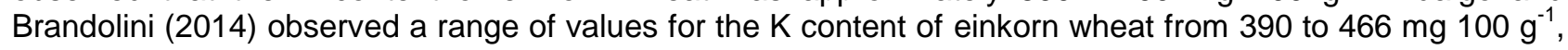
and Ertop and Atasoy (2019) and Vrancheva et al. (2019) found K levels in einkorn wheat of 496.3 and 420.1 mg $100 \mathrm{~g}^{-1}$, respectively.

The contents of $\mathrm{Zn}, \mathrm{Cu}$, and $\mathrm{Na}$ in the einkorn wheat in this study were not affected by $\mathrm{AM}+$. The average level of $\mathrm{Zn}$ observed here was less than the observations of $4.2 \mathrm{mg} 100 \mathrm{~g}^{-1}$ (Gabrovská et al.,

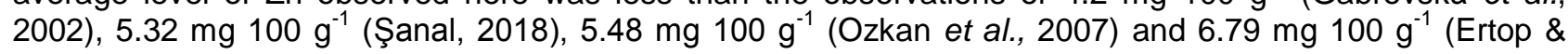
Atasoy, 2019). However, Ozkan et al. (2007) observed that the Zn content of einkorn wheat depended on its genotype. They found that the $\mathrm{Zn}$ content of 54 samples of einkorn wheat grown in the highlands was between 3.6 and $7.6 \mathrm{mg}^{100 \mathrm{~g}^{-1}}\left(5.1 \mathrm{mg} 100 \mathrm{~g}^{-1}\right.$ on average) and those grown in the lowlands had $\mathrm{Zn}$

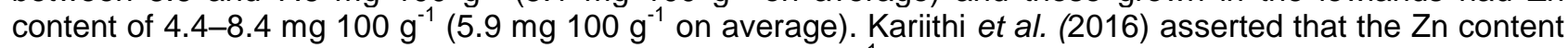

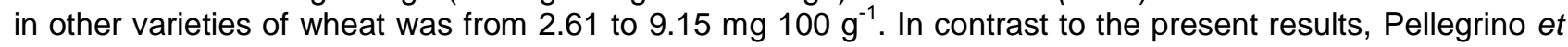
al. (2015) reported that $A M+$ increased the $Z n$ content of wheat grain by $10 \%$.

In this study the $\mathrm{Cu}$ content of the einkorn wheat was substantially less than previous observations. Ozkan et al. (2007), Abdel-Aal and Hucl (2014), Ertop and Atasoy (2019), and Vrancheva et al. (2019) all observed that the Cu content of einkorn wheat was $6 \mathrm{mg} \mathrm{kg}^{-1}$ or slightly higher.

Previous research showed the $\mathrm{Na}$ content of einkorn wheat was variable, with levels in the range of

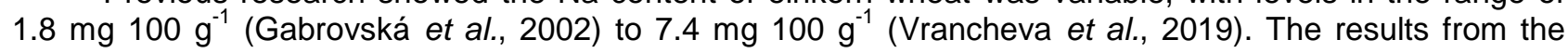
present study are within this range.

The treatment effects on fatty acid contents of AM grown from inoculated and non-inoculated seed are detailed in Table 2. In this study, the major constituent fatty acids were palmitic acid, oleic acid, and linoleic acid, all of which were affected $(P \leq 0.01)$ by the inoculation of einkorn wheat seed with AM. However, the differences between the treatments were fairly small $(\leq 4 \%)$.

Table 2 Comparison of fatty acid composition of einkorn wheat grown from seed inoculated with arbuscular mycorrhizae and control

\begin{tabular}{lrrrr}
\hline Fatty acids & Control & Inoculated & SE & $P$-value \\
\hline Lauric acid & 0.06 & $N D$ & 0.001 & \\
Myristic acid & $0.14^{\mathrm{a}}$ & $0.12^{\mathrm{b}}$ & 0.002 & 0.0020 \\
Pentadecylic acid & 0.08 & 0.09 & 0.001 & 0.1145 \\
Palmitic acid & $13.38^{\mathrm{a}}$ & $12.93^{\mathrm{b}}$ & 0.004 & $<0.0001$ \\
Margaric acid & $0.14^{\mathrm{b}}$ & $0.15^{\mathrm{a}}$ & 0.001 & 0.0007 \\
Stearic acid & $1.14^{\mathrm{a}}$ & $1.10^{\mathrm{b}}$ & 0.001 & $<0.0001$ \\
Arachidic acid & $0.23^{\mathrm{a}}$ & $0.22^{\mathrm{b}}$ & 0.001 & 0.0006 \\
Behenic acid & 0.20 & 0.20 & 0.001 & 0.2943 \\
\hline Cis palmitoleic acid & $0.25^{\mathrm{a}}$ & $0.18^{\mathrm{b}}$ & 0.001 & $<0.0001$ \\
Cis-10 heptadecenoic acid & $0.13^{\mathrm{a}}$ & $0.05^{\mathrm{b}}$ & 0.003 & $<0.0001$ \\
Oleic acid & $26.83^{\mathrm{b}}$ & $27.93^{\mathrm{a}}$ & 0.008 & $<0.0001$ \\
Cis-11 eicosenoic acid & $4.73^{\mathrm{a}}$ & $4.40^{\mathrm{b}}$ & 0.006 & $<0.0001$ \\
Erucic acid & $0.26^{\mathrm{a}}$ & $0.19^{\mathrm{b}}$ & 0.004 & 0.0040 \\
Nervonic acid & 0.15 & 0.14 & 0.002 & 0.1098 \\
\hline Linoleic acid & $50.49^{\mathrm{a}}$ & $50.42^{\mathrm{b}}$ & 0.011 & 0.0115 \\
Gamma linolenic acid & $\mathrm{ND}$ & 0.06 & 0.002 & \\
Alpha linolenic acid & $1.46^{\mathrm{b}}$ & $1.49^{\mathrm{a}}$ & 0.006 & 0.0144 \\
Cis-11,-14 eicosadienoic acid & 0.07 & 0.07 & 0.002 & 0.5300 \\
Arachidonic acid & $0.09^{\mathrm{a}}$ & $0.07^{\mathrm{b}}$ & 0.003 & 0.0089 \\
Cis-5, -8, -11, -14, cis-17 eicosapentaenoic acid & $0.18^{\mathrm{b}}$ & $0.19^{\mathrm{a}}$ & 0.001 & 0.0020 \\
\hline
\end{tabular}


In the present study, AM inoculation of einkorn wheat seed reduced the palmitic acid level and increased the levels of oleic and linoleic acids in the grain that was produced. In comparison, Vrancheva et al. (2019) found the palmitic, oleic and linoleic acid levels in einkorn wheat were $13.15 \%, 29.70 \%$, and $49.57 \%$, respectively.

The most common fatty acid in bread-type wheats is linoleic acid but, unlike einkorn wheat, these varieties contain more palmitic acid than oleic acid. Ruibal-Mendietaa et al. (2004) asserted that the main fatty acid contents of winter and spring wheat varieties were linoleic, palmitic, and oleic acids. The $\alpha$-linolenic and stearic fatty acids were relatively minor contributors to these wheats. Demir et al. (2015) found five major contributors to the fatty acid profile in einkorn wheat, namely linoleic acid (49.43\%), oleic acid (34.34\%), palmitic acid (10.27\%), linolenic acid (3.59\%), and eicosenoic acid (2.38\%). Likewise, Gabrovská et al. (2002) described the fatty acid profile of einkorn wheat as myristic acid, 0.18; myristoleic acid, 0.08; palmitic acid, 13.9; palmitoleic acid, 0.21; stearic acid, 0.87; oleic acid, 25.3; linoleic acid, 54.0; linolenic acid, 3.60; arachidic acid, 0.15; cis 11 eicosenoic acid, 1.36; behenic acid, 0.14 ; and erucic acid, $0.23 \mathrm{~g} / 100 \mathrm{~g}^{-1}$. Hidalgo and Brandolini (2014) reported that linoleic, oleic and palmitic acids were found in einkorn wheat at higher levels than 11 other fatty acids.

By forming groups of SFAs, MUFAs and PUFA, AM+ influenced SFAs significantly $(\mathrm{AM}+=14.81 \pm$ 0.01 vs. $A M-=15.37 \pm 0.01)$ and MUFAs $(A M+=32.89 \pm 0.01$ vs. $A M-=32.34 \pm 0.01)$, but not the PUFA content $(A M+=52.30 \pm 0.02$ vs. $A M-=52.29 \pm 0.02)$ (Figure 1). These changes led to an increased quantities of UFAs $(A M+=85.19 \pm 0.01$ vs. $A M-=84.63 \pm 0.01)$ and the ratios of UFA and PUFA to SFA.

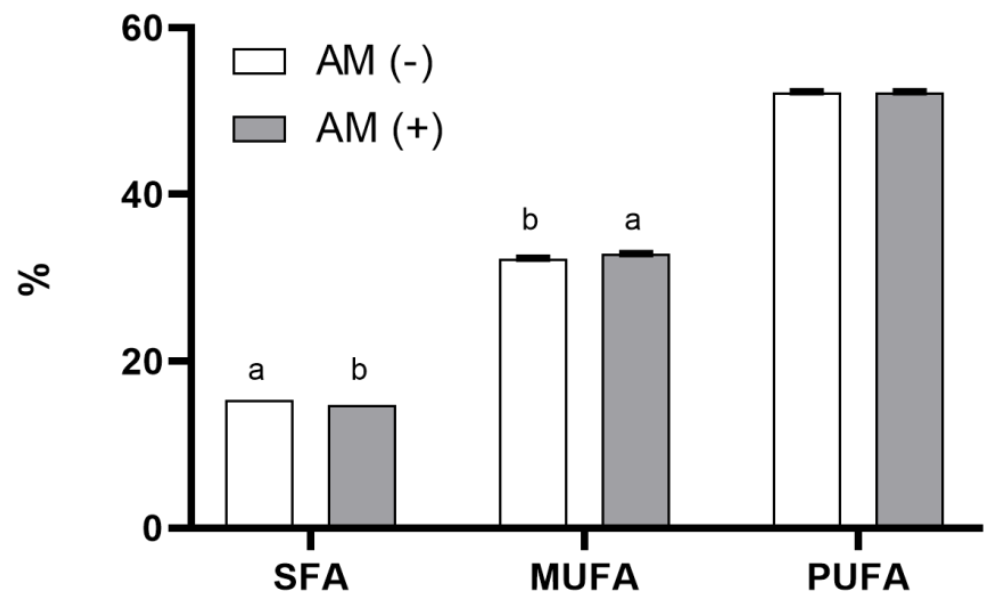

Figure 1 Comparison of total saturated fatty acids, monounsaturated fatty acids and polyunsaturated fatty acids of einkorn wheat grown from seed that inoculated with arbuscular mycorrhizae and control

SFA: saturated fatty acid; MUFA: monounsaturated fatty acid; PUFA: polyunsaturated fatty acid

${ }_{a, b}$ Values within fatty acid groups with different superscripts differ significantly at $P \leq 0.001$

Although the relative ratios in einkorn wheat and bread-type wheat varieties are the same, einkorn wheat contains 50\% more fat than bread-type wheat (Hidalgo \& Brandolini, 2014). Compared with breadtype wheat, einkorn wheat has more MUFAs, fewer PUFAs, and fewer SFAs (Hidalgo et al., 2009). In feeds and foods, the coexistence of high MUFA and PUFA concentrations and low SFA content contribute to the prevention of cardiovascular diseases. Monounsaturated fatty acids and PUFAs affect fat and cholesterol synthesis through reducing atherosclerosis and thrombosis. On the other hand, high MUFA and low PUFA contents ensure greater resistance to oxidation and longer shelf life (Hidalgo et al., 2009).

Decreasing the consumption of SFAs and increasing that of MUFAs is important in reducing cardiovascular diseases in people (Çakmakçı \& Tahmas Kayaoğlu, 2012). Armanino et al. (2002) and Kan (2015) reported that the total UFA levels of wheat were 75.31 - $77.34 \%$. Dinu et al. (2018) stated that because high levels of MUFA and PUFA and a low level of SFA coexist in einkorn wheat, the total cholesterol and low density lipoprotein cholesterol levels were low. 
Seferoğlu et al. (2006) reported that the fatty acid composition of seeds was affected to a great extent by ecological conditions. Dolde et al. (1999) suggested that the fatty acid composition of wheat was related to the differences in temperature at which the crop matured. However, it was not anticipated that ecological conditions would contribute to the present results in that the $\mathrm{AM}+$ and $\mathrm{AM}$ - crops were grown in close proximity.

\section{Conclusions}

Inoculation of einkorn wheat seed with AM played an effective role in increasing the levels of $\mathrm{DM}, \mathrm{Fe}$ and some UFAs. Thus, this treatment could improve the healthfulness qualities of bulgur made from einkorn wheat.

\section{Acknowledgements}

The authors thank Mr. N. Bodur for cooperation during to field trial.

\section{Authors' Contributions}

TA, SE and EC contributed to the project idea, design and execution of the study. SE, VKE, HE and EC were in charge of laboratory analyses. TA and SE were responsible for supervision and writing the manuscript.

\section{Conflict of Interest Declaration}

The authors declare that they have no competing interests.

\section{References}

Abdel-Aal, E.S.M., Hucl, P. \& Sosulski, W.F., 1995. Compositional and nutritional characteristics of spring einkorn and spelt wheats. Cereal Chem. 72(6), 621-624.

Abdel-Aal, E.S.M. \& Hucl, P., 2014. Einkorn: A functional wheat for developing high-lutein whole grain baked products. Cereal Foods World 59(1), 5-10.

Adıgüzel, E., 2019. Siyez buğdayı (Triticum monococcum) çölyak hastaları için alternatif olabilir mi?. Sağlık Bilimleri Dergisi 28(1), 27-32.

Akpınar Ç., 2011. The effects of mycorrhizae inoculation on yield and nutrient uptake of canola following by maize. PhD, Çukurova Üniversitesi Fen Bilimleri Enstitüsü Toprak Bilimi ve Bitki Besleme ABD, Adana, Turkey.

AOAC, 1990. Official methods of analysis. 14th ed. Association of Analytical Chemists, Arlington, Virginia, USA

Armanino, C., Acutis, R.D. \& Rosa Festa, A., 2002. Wheat lipids to discriminate species, varieties, geographical origins and crop years. Analytica Chimica Acta 454, 315-326.

Arzani, A. \& Ashraf, M., 2017. Cultivated ancient wheats (Triticum spp.): A potential source of health-beneficial food products. Comp. Rev. Food Sci. Food Safety 47, 477-488.

Brandolini, A. \& Hidalgo, A., 2011. Einkorn (Triticum monococcum) flour and bread. In: V. Preedy, R. Watson \& V. Patel (eds). Flours and breads and their fortification in health and disease prevention. Academic Press, Cambridge, Massachusetts, USA. Chap. 8, pp. 79-88.

Çakmakçı, S. \& Tahmas Kayaoğlu, D., 2012. Yağ asitlerinin sağlık ve beslenme üzerine etkilerine genel bir bakış. Akademik Gıda. 10(1), 103-113

Costanzo, A., Amos, D.C., Dinelli, G., Sferrazza, R.E., Accorsi, G., Negri, L. \& Bosi, S., 2019. Performance and nutritional properties of einkorn, emmer and rivet wheat in response to different rotational position and soil tillage. Sustainability 11, 6304. DOI: 10.3390/su11226304

Čurna, V. \& Lacko-Bartošová, M., 2017. Chemical composition and nutritional value of emmer wheat (Triticum dicoccon schrank): A review. Journal of Central European Agriculture. 18(1), 117-134.

Demir, M.K., Ünver, A., Arslan, D., Üçok, G., Terlemez, F. \& Türker, S., 2015. Characterization of einkorn (Triticum monococcum L. subsp. monococcum) wheat oil. Quality Assurance and Safety of Crops \& Foods 7(5),707-712.

Dinu, M., Whittaker, A., Pagliai, G., Benedettelli, S. \& Sofi, F., 2018. Ancient wheat species and human health: Biochemical and clinical implications. J. Nutr. Biochem. 52, 1-9.

Dolde, D., Vlahakis, C. \& Hazebroek, J., 1999. Tocopherols in breeding lines and effects of planting location, fatty acid composition, and temperature during development. J. American Oil Chem. Soc. 76, 349-355.

Emeksizoğlu, B., 2016. Kastamonu yöresinde yetiştirilen siyez (Triticum monococcum L.) buğdayının bazı kalite özellikleri ile bazlama ve erişte yapımında kullanımının araştırıması. Doktora Tezi, Ondokuz Mayıs Üniversitesi Fen Bilimleri Enstitüsü, Gıda Mühendisliği Anabilim Dalı, Samsun.

Erba, D., Hidalgo, A., Bresciani, J. \& Brandolini, A., 2011. Environmental and genotypic influences on trace element and mineral concentrations in whole meal flour of einkorn (Triticum monococcum L. subsp. monococcum). J. Cereal Sci. 54, 250-254.

Ertop, H.M., 2019. Comparison of industrial and homemade bulgur produced from einkorn wheat ( Triticum monococcum) and durum wheat (Triticum durum): Physicochemical, nutritional and microtextural properties. J.Food Process. Preserv. 43, e13863.

Ertop, H.M. \& Atasoy, R., 2019. Comparison of physicochemical attributes of einkorn wheat (Triticum monococcum) and durum wheat (Triticum durum) and evaluation of morphological properties using scanning electron microscopy and image analysis. Tarım Bilimleri Dergisi 25, 93-99. 
Gabrovská, D., Fiedlerová, V., Holasová, M., Mašková, E., Smrčinov, H., Rysová, J., Winterová, R., Michalová, A. \& Hutar, M., 2002. The nutritional evaluation of underutilized cereals and buckwheat. Food Nutr. Bull., 23(3 supplement), 246-249.

Gerdemann, J.W. \& Nicolson, T.H., 1963. Spores of mycorrhizal endogone species extracted from soil by wet sieving and decanting. Trans. Brit. Mycol. Soc. 46, 235.

Grain Nutrition Comparison, 2009. Nutritional qualities of grains. https://www.einkorn.com/wpcontent/uploads/2009/12/Grain-Nutrition-Comparison-Matrix.pdf

Hidalgo, A. \& Brandolini, A., 2014. Nutritional properties of einkorn wheat (Triticum monococcum L.). J. Sci. Food Agric. 94(4), 601-612. https://doi.org/10.1002/jsfa.6382

Hidalgo, A., Brandolini, A. \& Ratti, S., 2009. Influence of genetic and environmental factors on selected nutritional traits of Triticum monococcum. J. Agric. Food Chem. 57, 6342-6348.

Kan, A., 2015. Characterization of the fatty acid and mineral compositions of selected cereal cultivars from Turkey. Records of Natural Products 9(1), 124-134.

Karabak, S., Taşcı, R., Ceyhan, V., Özbek, K. \& Arslan, H.Y., 2019. İhsangazi tarlalarından soframıza kültür mirası siyez buğdayı. Toprak Su Dergisi. Özel Sayı: 86-93.

Kariithi, S.N., Abwa, S., Njau, P.N. \& Ndung'u, J.N., 2016. Evaluation of grain nutritional quality and resistant starch content in Kenyan bread wheat varieties. Afr. Crop Sci. J. 24(7), 417-428.

Kastamonu Ticaret Odası (Kastamonu Chamber of Commerce)., 2019. Kastamonu siyez bulguru. https://www.ci.gov.tr/Files/GeographicalSigns/413.pdf

Lùje, H., Mùller, B., Laustsen, A.M. \& Hansen, A., 2003. Chemical composition, functional properties and sensory profiling of einkorn (Triticum monococcum L.). J. Cereal Sci. 37, 231-240.

Milestone, 2009. Milestone SK-10 and SK-12 rotors user manual. Sorisole, Italy.

Nakov, G., Stamatovska, V., Necinova, L., Ivanova, N. \& Damyanova, S., 2016. Nutritional properties of einkorn wheat (Triticum Monococcum L). Review. 55th Sci. Conf. Ruse Univ., Bulgaria.

Ozkan, H., Brandolini, A., Torun, A., Altıntas, S., Eker, S., Kilian, B., Braun, H.J., Salamini, F. \& Cakmak, I., 2007. Natural variation and identification of microelements content in seeds of einkorn wheat (Triticum monococcum). In H.T. Buck, J.E. Nisi \& N. Salomón (edsi Wheat production in stressed environments, developments in plant breeding, Springer-Verlag GmbH, Heidelberg, Germany. Pp. 455-462.

Patijn, O., Voshol, P., Battjes, M. \& Nuijten, E., 2018. Health effects of ancient wheat species compared to modern wheat varieties. Louis Bolk Institute, Netherlands. Pp. 1-27.

Pellegrino, E., Opik, M., Bonari, E. \& Ercoli, L., 2015. Responses of wheat to arbuscular mycorrhizal fungi: A metaanalysis of field studies from 1975 to 2013 . Soil Biol. Biochem. 84, 210e217.

Ruibal-Mendietaa, N.L., Dekeyserb, A., Delacroixc, D.L., Mignoleta, E., Larondellea, Y. \& Meurensa, M., 2004. The oleate/palmitate ratio allows the distinction between whole meals of spelt (Triticum spelta $L$.) and winter wheat ( $T$. aestivum L.). J. Cereal Sci. 39, 413-415.

Sabiaa, E., Claps, S., Napolitano, F., Annicchiaricoa, G., Brunoa, A., Francavigliac, R., Sepea, L. \& Aleandri, L., 2015. In vivo digestibility of two different forage species inoculated with arbuscular mycorrhiza in Mediterranean red goats. Small Ruminant Res. 123(1), 83-87.

Sachambula, L., Hartman, I. \& Psota, V., 2015. Einkorn wheat malting quality. Sladovnická Kvalita Pšenice Jednozrnky 61, 320-325.

Schenck, N.C. \& Perez, Y. 1990. Manual for the identification of VA mycorrhizal fungi. Synergistic Publications, Gainesville, Florida, USA. Pp. 286.

Scott, J.M., Hill, C.B. \& Jessop, R.S. 1991. Growth chamber study of phosphorus applied as drilled granules or as seed coatings to wheat sown in soils differing in P-sorption capacity. Fertil. Res. 29, 281-287.

Seferoğlu, S., Seferoglu, H.G., Tekintas, F.E. \& Balta, F., 2006. Biochemical composition influenced by different locations in Uzun pistachio cv. (Pistacia vera L.) grown in Turkey. J. Food Comp. Analy. 19, 461-465.

Smith F.A. \& Smith S.E., 2011. What is the significance of the arbuscular mycorrhizal colonisation of many economically important crop plants? Plant and Soil 348, 63-79.

Somenahallya, A., DuPontb, J.I., Bradyc, J., McLawrencea, J., Northupb, B. \& Gowda, P., 2018. Microbial communities in soil profile are more responsive to legacy effects of wheat-cover crop rotations than tillage systems. Soil Biol. Biochem. 123, 126-135.

Şanal, T., 2018. Bazı yerel buğday çeşitlerinin kalite parametreleri. TÜRKTOB Dergisi. 38-43.

Tanacı, H., 2015. GC-FID ile bitkisel yağlarda yağ asidi metil esterlerinin tayini. GC Uygulama Notu-G002. Ant-Teknik.

Vrancheva, R., Krystev, L., Popova, A. \& Mihaylova, D., 2019. Proximate nutritional composition and heat-induced changes of starch in selected grains and seeds. Emirates J. Food Agric. 31(9), 718-724. 